\title{
Staphylinidae and Carabidae overwintering in wheat and sown wildflower areas of different age
}

\author{
T. Frank* and B. Reichhart \\ Zoological Institute, University of Bern, Baltzerstrasse 6, \\ CH-3012 Bern, Switzerland
}

\begin{abstract}
Species richness and abundance of staphylinid and carabid beetles overwintering in winter wheat fields and 1- to 3-year-old wildflower areas were investigated during 2000/2001 on 16 study sites in Switzerland. Abundance and species richness of overwintering staphylinids significantly increased with successional age of the wildflower areas and were always higher in older wildflower areas than in winter wheat. A similar but less distinct pattern was observed for the abundance and species richness of carabid beetles. The influence of habitat parameters (vegetation cover, fine sand content, organic matter, $\mathrm{pH}$, soil pore volume, surrounding landscape structure, habitat area) on the staphylinid and carabid assemblages based on the number of individuals per species and site was analysed using canonical correspondence analysis. Vegetation cover was the most significant parameter significantly characterizing both staphylinid and carabid assemblages. The amount of vegetation cover explained $15.7 \%$ of the variance, fine sand content accounted for $13.3 \%$ and surrounding landscape structure for $10.9 \%$ of the variance in the staphylinid assemblage. In the carabid assemblage, vegetation cover was the only significant factor, explaining $24.7 \%$ of the variance. This study showed for the first time that the significance of wildflower areas as a reservoir for hibernation for generalist predatory beetles increases with progressing successional age.
\end{abstract}

\section{Introduction}

Whereas many pest insects have been observed overwintering in arable crop fields (Keller, 1994), most predatory arthropods living in arable crops invade seminatural habitats for hibernation (Sotherton, 1984, 1985). This reveals that semi-natural habitats are important overwintering sites, particularly for potentially beneficial arthropods such as Staphylinidae and Carabidae. The removal of semi-natural habitats due to the intensification of agricultural practice can lead to a reduction in overwintering sites. Such undisturbed overwintering sites serve as dispersal centres for predatory arthropods to colonize

${ }^{*}$ Fax: +410316313188

E-mail: thomas.frank@zos.unibe.ch adjoining fields, resulting in high predator densities in nearby arable crops (Desender et al., 1981). Flying insects such as staphylinid beetles are able to colonize arable crops rapidly after their hibernation in semi-natural habitats, whilst epigeic carabids take longer to reach the centre of a field (Thomas et al., 1991). A positive relationship between the density of several carabid species in the field with their overwintering densities in the previous winter in field boundaries has been observed by Coombes \& Sotherton (1986). In addition, Collins et al. (2002) showed that epigeic predators including carabids, staphylinids and spiders were able to clearly reduce aphid densities in winter wheat.

Wildflower areas (a term synonymous with wildflower or weed strips) are a special type of semi-natural man-made habitat, designed to enhance overall arthropod diversity, and have been progressively introduced into the Swiss agricultural landscape over the last decade (Nentwig, 2000). 
Previously, wildflower areas have been shown to serve as appropriate overwintering sites (Bürki \& Hausammann, 1993; Lys \& Nentwig, 1994), and to provide a better food supply and harbour a higher species richness of epigeic carabids, spiders (Lys et al., 1994; Zangger et al., 1994; Frank \& Nentwig, 1995) and flower-visiting insects (Frank, 1998) compared to arable crops. In contrast to these studies, the present investigation focuses on the early successional stage of wildflower areas as the effects of habitat succession on single arthropod predators and predator assemblages have been scarcely explored (Siemann et al., 1999). A recent study has shown that the reproduction and nutritional condition of the predatory beetle Poecilus cupreus (Linnaeus) (Coleoptera: Carabidae) increased significantly with habitat age in wildflower areas (Barone \& Frank, 2003). There exists only one study that deals with the enhancement of carabid richness and abundance during early succession in wildflower areas (Mosimann, 2002). However, there is no published information available about species richness and abundance of staphylinid and carabid beetles overwintering in wildflower areas during the first years of succession.

Staphylinid beetles occur in particularly high numbers of both species and individuals in arable land (Topp \& Wiebke, 1980), and carabids are considered important natural control agents of pests due to their polyphagous, predatory feeding behaviour and their high abundances in similar habitats (Sunderland \& Vickerman, 1980; Thomas et al., 2001; Symondson et al., 2002). Over the last decades carabid beetles have suffered from the intensification of agriculture and have declined in abundance and species richness in agroecosystems (Basedow, 1990; Kotze \& O'Hara, 2003). Staphylinid and carabid beetles are considered to have bioindicator values for cultivation impact (Bohac, 1999; Kromp, 1999). Therefore, it was considered important to study whether habitat diversification through the establishment of wildflower areas can enhance the number of species and individuals of staphylinids and carabids overwintering in the agricultural landscape.

The species richness of several groups of insects was observed to increase with successional age (Brown \& Hyman, 1986; Brown \& Southwood, 1987), and wildflower areas are known to be appropriate overwintering sites for Staphylinidae and Carabidae (Pfiffner \& Luka, 2000). Therefore it was hypothesized that the abundance and species richness of staphylinid and carabid beetles overwintering in wildflower areas should increase with advancing age, and be greater in wildflower areas than in winter wheat fields (hypothesis 1). A dense vegetation cover and a well-developed layer of litter are considered to be important characteristics of a habitat that make it an attractive overwintering site for arthropods (Schaefer, 1976; Wiedemeier \& Duelli, 1999). Moreover, certain insects have been shown to respond to increased surrounding landscape structure (Ricketts et al., 2001; Steffan-Dewenter et al., 2002). Therefore, staphylinid and carabid assemblages were predicted to correlate with these parameters (hypothesis 2).

\section{Materials and methods}

\section{Research area and study sites}

The study was carried out in the Swiss plateau around Bern in a region of about $20 \times 23 \mathrm{~km}$, representing typical Swiss agricultural landscapes at an altitude of
480-655 m a.s.1. (fig. 1). Four treatments (1-, 2-, 3-year-old wildflower areas, winter wheat fields) with four replicates each $(n=16)$ were sampled in winter $2000 / 2001$. The size of the study sites ranged from 0.2 ha to 2.7 ha with a mean size of 0.8 ha, and did not significantly differ among wheat fields and the three successional stages of the wildflower areas (ANOVA: $\mathrm{F}=1.253, P=0.334, \mathrm{n}=16$, d.f. $=3$ ). This meant that differences in beetle abundance and species richness among treatments could not be attributed to differences in the size of the study sites. Wildflower areas are sown using mixtures containing 25 native herbaceous plant species (Günter, 2000) and are usually maintained for three or four years at the same place. All wildflower areas studied were adjacent to crop fields and created at sites where cereals had been grown previously. The wildflower areas were sown by farmers in April during 1998 (3-year-old, WA3), 1999 (2-yearold, WA2) and 2000 (1-year-old, WA1). For the comparison of diversity between wildflower areas and a representative crop, winter wheat (WW) was chosen because it is the most widespread crop in Switzerland. Winter wheat was sown in October 2000 with maize as the previous crop in all wheat fields. None of the wheat fields received insecticides. All study sites were selected to lie in the same climate zone providing similar site conditions in terms of altitude, mean annual rainfall and temperature. For analysis, the wheat fields and the three successional stages of wildflower areas were considered as four different habitat types.

\section{Beetle sampling}

To determine the species richness and abundance of staphylinid and carabid beetles overwintering in the 16 study sites, soil core samples (diameter $10 \mathrm{~cm}$; depth $10 \mathrm{~cm}$ ) were taken nine times (from mid-November 2000 to midMarch 2001). A depth of $10 \mathrm{~cm}$ was chosen because many more beetles are known to overwinter in the upper $5 \mathrm{~cm}$ of the soil compared to 6-20 cm depth (Bürki \& Hausammann, 1993; Dennis et al., 1994). However, a depth of $10 \mathrm{~cm}$ meant that some rove and ground beetles that occupy the lower levels in soil, including Lathrobium spp. (Staphylinidae) and Clivina fossor (Linnaeus) (Carabidae), may have been undersampled. At each date, four samples were taken leading to 36 samples per site. Thus a total area of $2827 \mathrm{~cm}^{2}$ was surveyed per site. The samples were taken at randomly chosen places in the central part of each study site. The samples were brought into the laboratory where they were extracted for six days in a MacFadyen apparatus (MacFadyen, 1961). Numbers of staphylinid and carabid beetles were expressed as population density per $\mathrm{m}^{2}$. Adult Carabidae and Staphylinidae (except for Aleocharinae) were identified to species level, and the nomenclature followed Freude $e t$ al. (1964, 1976) and Lohse \& Lucht (1989). The members of the subfamily Aleocharinae were separated into morphospecies according to morphological characteristics. Larvae, which reached only very small numbers, were not considered.

\section{Soil and environmental parameters}

Seven soil and environmental parameters (= habitat parameters), which were shown to be important for the distribution of staphylinid and carabid beetles in agroecosystems (Baker \& Dunning, 1975; Thiele, 1977; D'Hulster \& Desender, 1984; Good \& Giller, 1991; Holopainen et al., 1995; Bohac et al., 1999; Pfiffner \& Luka, 


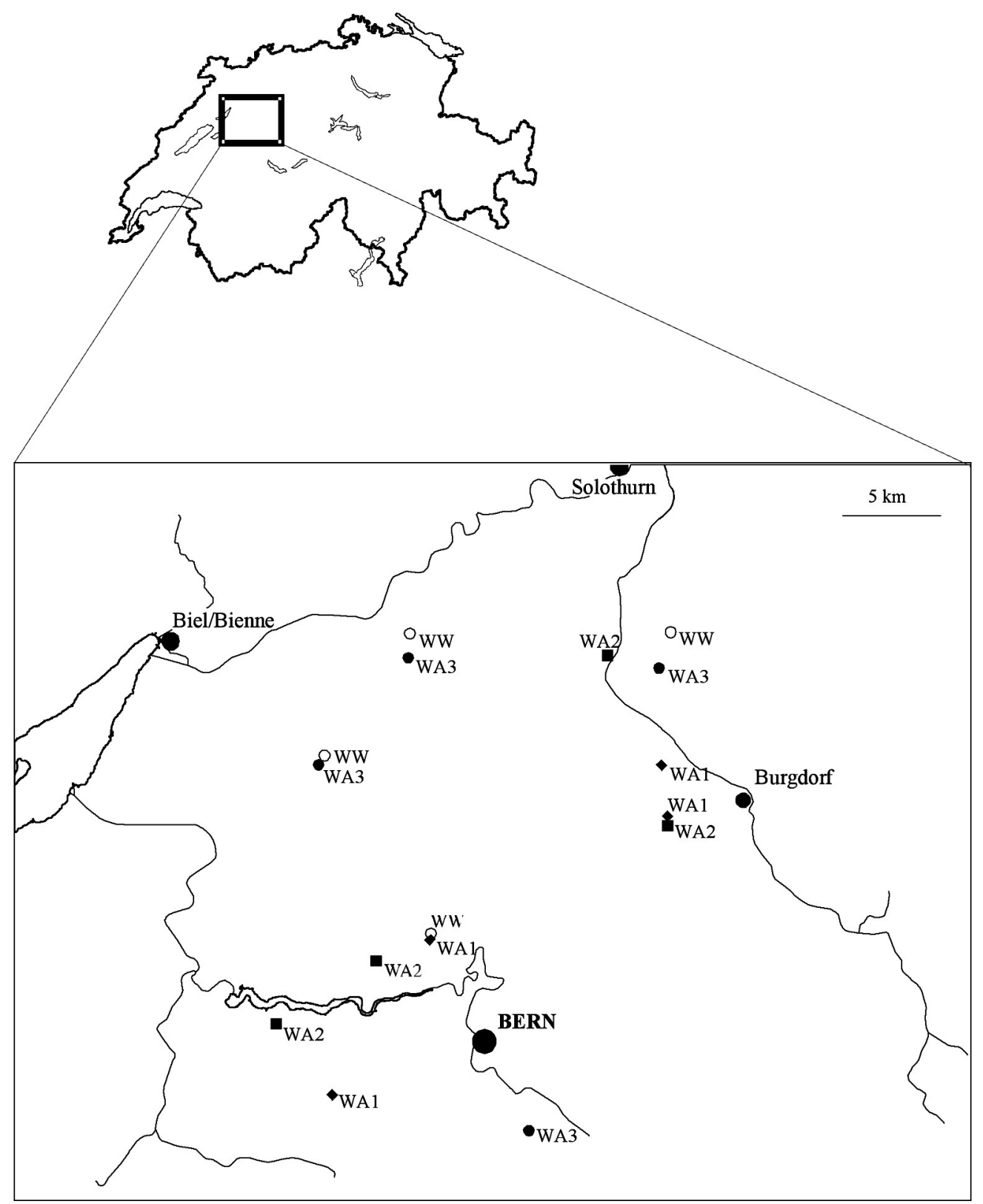

Fig. 1. Map showing the location of the 16 study sites on the Swiss plateau in the region of Bern - Biel - Solothurn - Burgdorf. $\bigcirc$, Winter wheat fields (WW); $\bullet$, 1-year-old wildflower areas (WA1); $\mathbf{\bullet}, 2$-year-old wildflower areas (WA2); 0 , 3-year-old wildflower areas (WA3).

2000), were recorded to examine their influence on the staphylinid and carabid communities.

Percentage vegetation cover was determined once at the end of November 2000. At five $16 \mathrm{~m}^{2}$ areas in each study site, the proportion of living plants as well as dead plant material covering the surface was estimated. For determining the organic matter five soil samples (diameter $5 \mathrm{~cm}$; depth $10 \mathrm{~cm}$ ) per study site were taken in December 2000. In the laboratory the samples were dried for seven days at room temperature. Thereafter stones were removed and the soil was crushed and sieved ( $2 \mathrm{~mm}$ mesh). Thirty grams of each soil sample were dried overnight at $105^{\circ} \mathrm{C}$, cooled in a desiccator and reweighed. Then the samples were placed in an oven and heated for $2 \mathrm{~h}$ at $430^{\circ} \mathrm{C}$ in order to burn off the organic matter. Afterwards the samples were cooled again and reweighed. Percentage weight loss corresponded to the amount of organic matter. Five soil samples (diameter $5 \mathrm{~cm}$; depth $10 \mathrm{~cm}$ ) per study site were taken in December 2000 to evaluate the $\mathrm{pH}$. The soil samples were dried for seven days at $40^{\circ} \mathrm{C}, 20 \mathrm{~g}$ of crushed soil were suspended for $5 \mathrm{~min}$ with $\mathrm{KCl}$ at a ratio of 1:2.5 KCl vs. soil, and the $\mathrm{pH}$ was measured with a glass rod electrode. For determining the volume of the large pores in the soil, five soil samples (diameter $5 \mathrm{~cm}$; depth $10 \mathrm{~cm}$; two cylinders with $5 \mathrm{~cm}$ each) were taken at 
each study site in December 2000. The large pores were measured because they can provide space for staphylinids and carabids to hide and gain protection from desiccation or predation. In the laboratory, the soil samples were soaked with water and the water content (\% of volume) was measured with a time-domain-reflectometry (TDR)-probe (supplier: DMP AG, Fehraltorf, Switzerland). Afterwards the samples were left to drip for 15 min (to let the air back into the larger pores) and the water content was measured again. The difference between the two measurements gave the percentage pore volume in the upper $10 \mathrm{~cm}$ of the soil. For measuring the fine-sand content, five soil samples were taken from each site in December 2000. These were dried for seven days, and the large particles removed with a $2 \mathrm{~mm}$ sieve. The remaining material $(<2 \mathrm{~mm})$ was separated using a 'wet siever' to determine the proportion of fine, medium and coarse sand (fine sand: particle size 63-200 $\mu \mathrm{m}$, medium sand: $201-630 \mu \mathrm{m}$, coarse sand: $631-2000 \mu \mathrm{m})$. The three fractions were weighed after drying and the percentage of fine sand used in further analyses. The methods used for the determination of the soil parameters were based on the methods of Brucker \& Kalusche (1976), Janetschek (1982), Kuntze et al. (1988) and Dunger \& Fiedler (1997). Habitat area, expressed as the size of each study site, and the surrounding landscape structure were mapped in spring 2001. The latter was surveyed by measuring the area of 'natural habitats' (= extensively managed meadows, sown wildflower areas, ruderal areas, orchards, hedges, forest and single trees) in a $150 \mathrm{~m}$ wide perimeter surrounding each site. Habitat area and the percentage of surrounding natural landscape were used for further analyses.

\section{Statistical analyses}

For the analyses of the data, all samples were pooled over time, resulting in one sample per site. If necessary, variables were logarithmic or square root transformed to achieve normal distribution and homogeneity of variance. Differences in the density of the most abundant individual beetle species between the four habitat types were tested for significance with one-way-ANOVA, followed by Tukey's multiple comparison test. The same procedure was performed to test for differences in overall staphylinid and carabid species richness and density. Where ANOVA showed no significance $(P>0.05)$, contrasts between groups of interest were calculated to test for general group effects. All these procedures were carried out with SPSS 11.5 (SPSS, 2003). Spearman's correlation coefficient was used to test for successional trends in beetle richness and abundance within wildflower areas. For that, wheat fields were excluded from the analysis.

Canonical correspondence analysis was used to calculate the influence of habitat parameters on the staphylinid and carabid assemblages based on the number of individuals per species and site, using the programme Canoco 4.5 (Ter Braak \& Smilauer, 2002). For that, species represented by less than three individuals were omitted to minimize random effects and sampling errors. Canonical correspondence analysis (CCA) was performed to characterize the influence of all habitat parameters on the beetle assemblages using untransformed data. Partial CCA was performed with those parameters that significantly explained any variance. The amount of the variance explained by each remaining parameter was calculated separately, after eliminating the variance due to the other (partialed) parameters, which were used as covariables (Jeanneret et al., 1999). The significance for each parameter in the canonical correspondence analysis was obtained by a Monte Carlo test run with 499 permutations.

\section{Results}

Forty six staphylinid and 20 carabid beetle species were collected during the survey. Excluding two rather abundant species of the subfamily Aleocharinae which were not determined to species level, the most abundant staphylinid beetles were Anotylus rugosus (Fabricius), Platystethus nitens (Sahlberg), Gabrius pennatus (Sharp), Carpelimus corticinus (Gravenhorst) and Lathrobium longulum (Gravenhorst). The density of $A$. rugosus increased gradually from winter wheat to 2-year-old-wildflower areas and remained at a high level in the 3-year-old wildflower areas (see table 1 for statistical differences). Platystethus nitens and C. corticinus were regularly distributed over wheat, 1- and 2-year-old wildflower areas, but reached much higher densities in 3year-old wildflower areas. The numbers of G. pennatus overwintering in all successional stages of wildflower areas were noticeably higher than those in winter wheat fields, with significantly higher numbers in 1- and 2-year-old wildflower areas compared to wheat. Moreover, numbers of G. pennatus were significantly higher in 2-year-old compared to 1-year-old wildflower areas. A similar but less distinct pattern was observed for L. longulum as well. Carabid beetles were mostly represented by C. fossor, Agonum mülleri (Herbst), Pterostichus anthracinus (Illiger), Acupalpus meridianus (Linnaeus) and Tachys bistriatus (Duftschmid).

Table 1. Mean number $\mathrm{m}^{-2}$ of the most abundant staphylinid species overwintering in winter wheat (WW) and 1- to 3-year-old wildflower areas (WA1-WA3) in the Bern region, Switzerland.

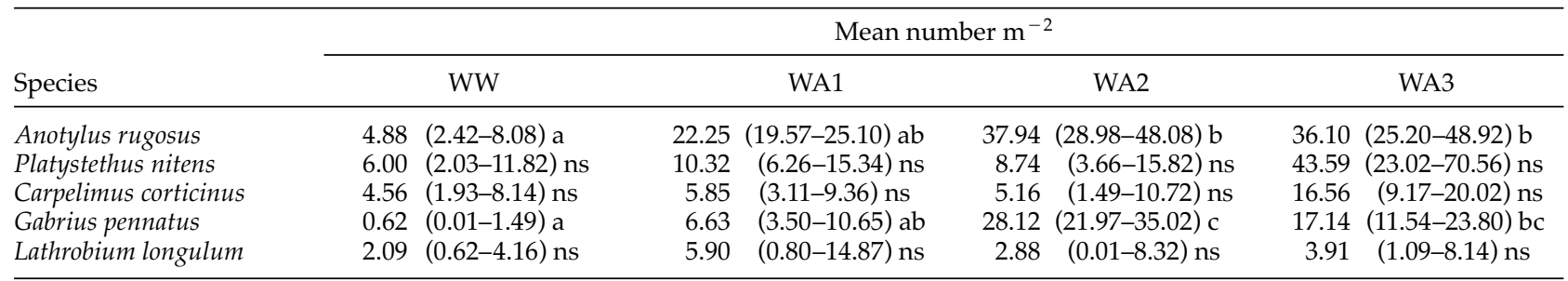

Numbers in brackets are confidence intervals of 1 SE. For each species, different letters in the same row denote significant differences between habitat types (Tukey, $P<0.05$; ns $=$ not significant). For statistical analyses, $\sqrt{X}+0.5$ transformed values were used, and backtransformed values are shown. 
However, they were recorded in too low numbers for statistical analysis among treatments.

Considering all species of a beetle family together, the numbers of adult staphylinid individuals gradually increased with successional age and were significantly higher in 3-year-old wildflower areas compared to wheat and 1-year-old areas (ANOVA: $\mathrm{F}=8.257, P=0.003, \mathrm{n}=16$, d.f. $=3$, fig. 2A). During the establishment period of the wildflower areas staphylinid abundance increased significantly with age (Spearman $\mathrm{r}_{\mathrm{s}}=0.887, P<0.001, \mathrm{n}=$ 12). Although there was a tendency for density to increase with successional age, the abundance of carabids was not significantly different between the four habitat types (ANOVA: $\mathrm{F}=2.017, P=0.165, \mathrm{n}=16$, d.f. $=3$, fig. $2 \mathrm{~B}$ ). To test for a general group effect on the abundance of carabids, the contrast between winter wheat and 2- to 3-year-old wildflower areas was calculated. This showed that the number of carabid individuals in winter wheat was significantly lower than in 2- and 3-year-old wildflower areas $(\mathrm{t}=2.40, P=0.034$, d.f. $=12)$. Staphylinid species numbers increased with successional age and were significantly higher in the oldest wildflower areas than in the 1-year-old areas and winter wheat fields (ANOVA: F =
10.837, $P=0.001, \mathrm{n}=16$, d.f. $=3$, fig. $2 \mathrm{C})$. Within the wildflower areas staphylinid species increased significantly with age (Spearman $\mathrm{r}_{\mathrm{s}}=0.834, P=0.001, \mathrm{n}=12$ ). Carabid species numbers in 2- and 3-year-old wildflower areas differed significantly from those in wheat fields (ANOVA: F $=4.938, P=0.018, \mathrm{n}=16$, d.f. $=3$, fig. 2D).

The canonical correspondence analysis (CCA) model that characterized the staphylinid assemblage by including all habitat parameters, explained $62 \%$ of the total variance. The three habitat parameters that significantly contributed to the model were introduced in a partial canonical correspondence analysis to rank them according to explained variance. The amount of vegetation cover explained $15.7 \%$ of the variance $(\mathrm{F}=3.16, P=0.002)$, fine sand content accounted for $13.3 \%(\mathrm{~F}=2.67, P=0.004)$ and surrounding landscape structure for $10.9 \%$ of the variance $(F$ $=2.19, P=0.004$; table 2). Canonical correspondence analysis including all habitat parameters explained $70.8 \%$ of the variance in the carabid assemblage. Vegetation cover, the only significant habitat parameter, was introduced separately in a CCA model and accounted for $24.7 \%$ (F = $3.29, P=0.006)$ of the variance in the carabid assemblage (table 2). Of the three factors determining beetle
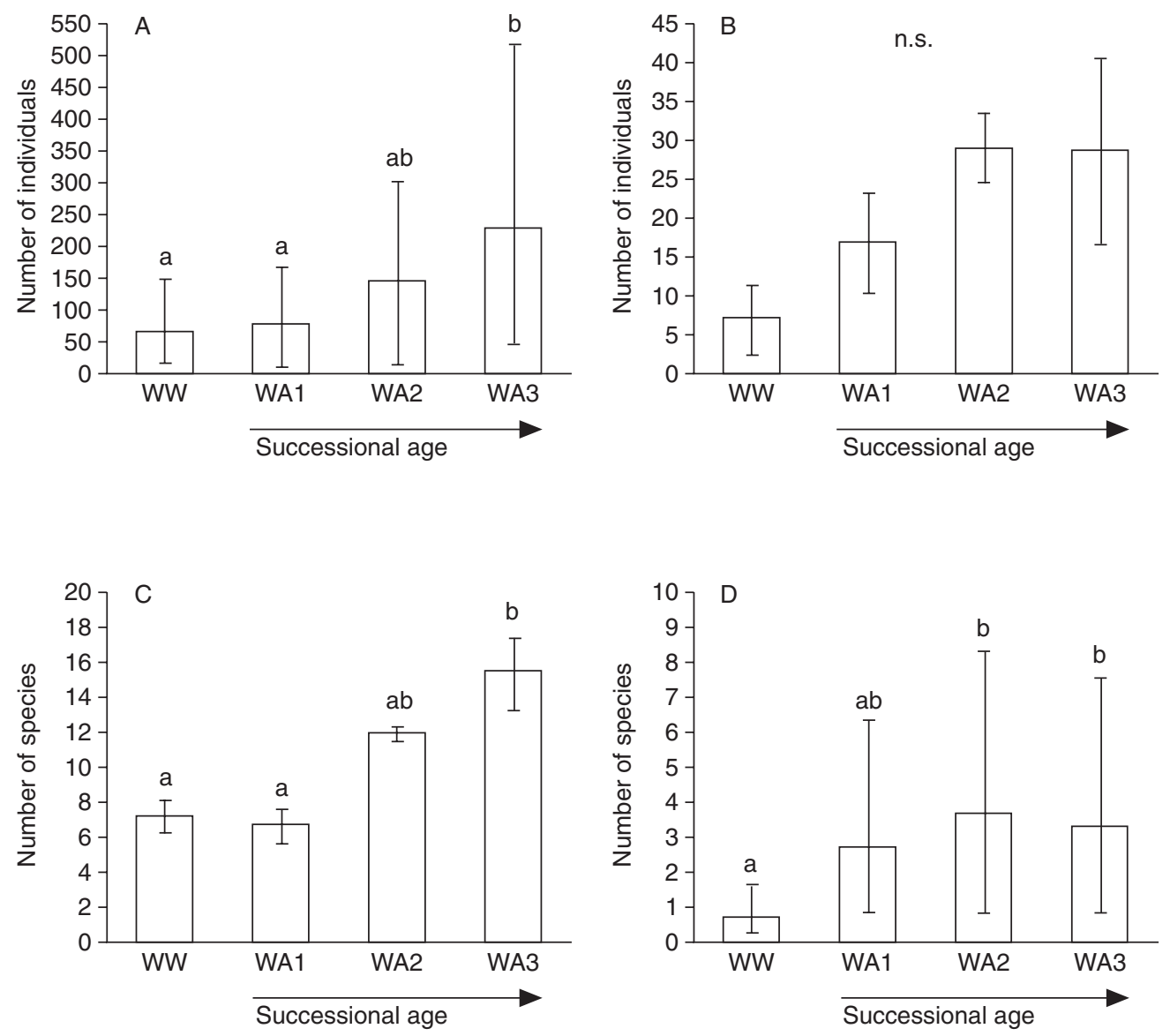

Fig. 2. Mean number of A) staphylinid and B) carabid individuals $\mathrm{m}^{-2}$ and C) staphylinid and D) carabid species overwintering in the four habitat types. Note that for A and D back-transformed values with asymmetrical confidence intervals of 1 SE are given, because analyses of these data were calculated with $\log$ (staphylinid individuals) and $\log (x+1)$ transformed data (carabid species). Analyses for $\mathrm{B}$ and $\mathrm{C}$ were performed with untransformed data, and means $\pm \mathrm{SE}$ are shown. Different letters denote significant differences (Tukey, $P$ $<0.05, \mathrm{n}=16$, d.f. =3). n.s. = not significant. WW, winter wheat fields; WA1-WA3, 1- to 3-year-old wildflower areas. 
Table 2. Canonical correspondence analyses (CCA) showing the influence of key habitat parameters on assemblages of Staphylinidae and Carabidae. Significance of parameters was tested using a Monte Carlo procedure with 499 permutations.

\begin{tabular}{|c|c|c|c|c|}
\hline Specifications of CCA & \multicolumn{3}{|c|}{ Staphylinidae } & $\begin{array}{c}\text { Carabidae } \\
\begin{array}{c}\text { Vegetation } \\
\text { cover }\end{array}\end{array}$ \\
\hline Sum of all canonical eigenvalues & 0.289 & 0.252 & 0.206 & 0.623 \\
\hline Inertia explained $(\%)$ & 15.7 & 13.3 & 10.9 & 24.7 \\
\hline F-ratio $\mathrm{T}$ & 3.16 & 2.67 & 2.19 & 3.29 \\
\hline
\end{tabular}

communities, fine sand (ANOVA: $\mathrm{F}=0.275, P=0.842, \mathrm{n}=16$, d.f. $=3$ ) and surrounding landscape structure (ANOVA: $\mathrm{F}=$ 1.331, $P=0.310, \mathrm{n}=16$, d.f. $=3$ ) were not significantly different between the four habitat types. However, vegetation cover was significantly higher in all successional stages of wildflower areas than in winter wheat fields (Tukey: $P<0.001, \mathrm{n}=16$ ).

\section{Discussion}

The abundance and species richness of overwintering adult staphylinids significantly increased with successional age of the wildflower areas and were always higher in older wildflower areas than in winter wheat. A similar but less distinct pattern was also observed for abundance and species richness of adult carabids. Thus, the potential of wildflower areas as a reservoir for these generalist predatory beetles was shown to increase with increasing successional age, thereby supporting hypothesis 1 . Increasing the number of overwintering predators may lead to higher predator densities in adjoining arable crops (Coombes \& Sotherton, 1986), thereby possibly enhancing the beneficial efficacy of these insects. Individual beetle species, e.g. the staphylinid Tachyporus hypnorum (Linnaeus) and the carabid Demetrias atricapillus (Linnaeus), were observed to readily colonize arable crops after hibernation in adjoining semi-natural habitats (Thomas et al., 1991). Unfortunately, nothing is known about the dispersal pattern of these most numerous beetles observed in the present study. Presumably, the more beetles that overwinter in a wildflower area the higher will be the probability that a large proportion will invade adjacent arable fields. Of the most abundant staphylinids observed, A. rugosus, G. pennatus and Lathrobium sp. are known to kill nematodes, mites and various Diptera (Coaker \& Williams, 1963; Andersen et al., 1983; Tomlin et al., 1985; Good \& Giller, 1986), i.e. groups of invertebrates containing potential pest species. Among the abundant carabid species, A. mülleri is a known predator (Hengeveld, 1980), and this species, together with $P$. anthracinus were observed to kill aphids and dipteran larvae in the laboratory (Frank, unpublished). Moreover, C. fossor is considered a predator even though it may sometimes be injurious to arable crops (see Desender \& Alderweireldt, 1988). Overall, it must be stated that the sampling design used had a low power to resolve differences between the four habitat types studied. According to Cohen (1977) the power of the ANOVAs shown in fig. 2 was 0.183 for large, 0.097 for medium, and 0.057 for small effect size. Thus, significant ecological effects were only found when the differences between the means were large. Despite the low power, significant effects $(P<$
0.05) were observed in three of the four situations using Tukey HSD test, which shows that there were clear differences among the four groups (fig. 2A,C,D). By contrast, possible differences among the groups in fig. $2 \mathrm{~B}$ could not be detected. However, the calculation of contrasts between groups of interest enabled us to detect significant differences in carabid abundance between winter wheat and 2- to 3year-old wildflower areas. This result can be explained by the fact that calculating contrasts between groups is more powerful than performing multiple comparison tests.

Lys \& Nentwig (1994), who explored arthropod overwintering densities in a cereal field divided up by $1.5 \mathrm{~m}$ wide 2-year-old wildflower areas without considering their successional age, found significantly higher overwintering populations of a more diverse carabid and staphylinid assemblage in the wildflower areas than in cereal stands between the wildflower areas. They observed distinctly higher abundances of overwintering adult staphylinids compared to carabids, similar to the present investigation. Of the five most abundant staphylinids recorded in this study that are considered eurytopic and mainly hygrophilous species (Koch, 1989), four species were also observed by Lys \& Nentwig (1994). Additionally, they found similar distribution patterns to those observed by us. For example, in both studies A. rugosus and G. pennatus reached noticeably higher densities in wildflower areas than in wheat fields, and in wheat L. longulum reached about half the abundance of that of 2-year-old wildflower areas. Similar to our study, Pfiffner \& Luka (2000) observed many more overwintering staphylinid and carabid beetles in 2-year-old wildflower areas than in arable crops. Overall, the high overwintering densities of polyphagous predators in wildflower areas contributed to a noticeable increase in predator densities within adjoining arable crops early in the season, which is important for effective regulation of pest organisms (Altieri \& Letourneau, 1984). For example, this has been shown for carabids (Lys, 1994). Based on the present results, this effect appears to depend upon successional age of wildflower areas because, in contrast to 2- and 3-year-old wildflower areas, the numbers of beetles overwintering in 1-year-old areas were never significantly higher than in wheat fields. With advancing successional age, predators may profit from undisturbed developmental conditions in the wildflower areas where no pesticides and only extensive mechanical methods are allowed. Whereas the abundance and species richness of overwintering staphylinids continuously increased with successional age of the wildflower areas, abundance and richness of carabids did not increase from the second to the third year. Similarly, carabid numbers overwintering in grassy strips established 
within arable crops clearly increased from the first to the second year, but remained approximately the same from the second to the third year (Thomas et al., 1992). These findings suggest that maximum overwintering densities of Carabidae tend to occur within two years. According to the results of the present study, however, it is not clear whether maximum overwintering densities of Staphylinidae were already reached in the third year of succession. This is difficult to clarify as there are only a few wildflower areas older than three or four years available for investigation. This is because from the third or fourth year onwards grassy vegetation begins to dominate in wildflower areas (Günter, 2000), and farmers usually refuse to maintain grassy seminatural habitats and therefore remove them after this time.

In support of hypothesis 2, assemblages of overwintering staphylinid and carabid beetles were best explained by vegetation cover, which in general appeared to be an important factor regulating high densities of overwintering arthropods (Thomas et al., 1992). Because of its insulating potential, patches of ground with a high vegetation cover tend to freeze less frequently or suffer less intense frosts thereby protecting arthropods (Sotherton, 1985). This is supported by Bürki \& Hausammann (1993) who observed the highest densities of arthropods overwintering in wildflower areas under plant species with high vegetation cover (e.g. Achillea millefolium L., Arctium minus Bernh., Symphytum officinale L.), and lowest arthropod densities under plants with little vegetation cover (e.g. Agrostemma githago L., Chenopodium polyspermum L.). Similarly, a comparison of different grass treatments as overwintering sites for predatory arthropods showed that the highest arthropod densities occurred in tall-growing grasses that formed dense trussocks (Collins et al., 2003). Fine sand significantly explained part of the species assemblage of staphylinid beetles and thus appeared to be an appropriate substrate for them to overwinter in. With their slim bodies staphylinids are adapted to penetrate soil layers with a large content of fine sand that cannot be used to such an extent by larger and broader carabids. Furthermore, the species composition of staphylinid beetles was supported by a richly structured landscape because, in accordance with hypothesis 2, staphylinid assemblage was explained to some extent by the surrounding landscape structure. Only a small amount of published information is available about the response of predatory arthropod assemblages to landscape complexity. Carabid species richness was recently shown to relate positively to landscape structure (Purtauf et al., 2002). Our study appears to be the first one showing a positive response of staphylinid assemblages to the amount of natural landscape surrounding a site.

This study showed there was an increase in abundance and species richness of overwintering adult staphylinids and carabids with increasing age of wildflower areas and detected larger beetle numbers in older wildflower areas than in 1-year-old winter wheat. These results highlight the significance of maturing wildflower areas as overwintering places for generalist predatory beetles. Thus it is necessary to maintain wildflower areas for several years in order to maximize their beneficial effects.

\section{Acknowledgements}

The authors thank K. Sunderland and two anonymous referees for critical comments on the manuscript, and are grateful to J. Zettel and R. Mailänder who helped us with soil analyses, and J.-P. Airoldi for statistical advice. G. Cuccodoro (Staphylinidae) and C. Huber (Carabidae) checked doubtful species.

\section{References}

Altieri, M.A. \& Letourneau, D.K. (1984) Vegetation diversity and insect pest outbreaks. CRC Critical Reviews in Plant Sciences 2, 131-169.

Andersen, A., Hansen, A.G., Rydland, N. \& Oyre, G. (1983) Carabidae and Staphylinidae (Coleoptera) as predators of eggs of the turnip root fly Delia floralis (Diptera, Anthomyiidae) in cage experiments. Journal of Applied Entomology 95, 499-506.

Baker, A.N. \& Dunning, R.A. (1975) Some effects of soil type and crop density on the activity and abundance of the epigeic fauna, particularly Carabidae, in sugar-beet fields. Journal of Applied Ecology 12, 809-818.

Barone, M. \& Frank, T. (2003) Habitat age increases reproduction and nutritional condition in a generalist arthropod predator. Oecologia 135, 78-83.

Basedow, T. (1990) Effects of insecticides on Carabidae and the significance of these effects for agriculture and species number. pp. 115-125 in Stork, N.E. (Ed.) The role of ground beetles in ecological and environmental studies. Andover, Intercept.

Bohac, J. (1999) Staphylinid beetles as bioindicators. Agriculture Ecosystems and Environment 74, 357-372.

Bohac, J., Jedlicka, P. \& Frouz, J. (1999) Changes in communities of staphylinid beetles (Coleoptera, Staphylinidae) during secondary succession in abandoned fields. pp. 19-25 in 5th Central European Workshop on Soil Zoology, 27-30 April 1999 Ceske Budejovice, Central European Workshop on Soil Zoology.

Brown, V.K. \& Hyman, P.S. (1986) Successional communities of plants and phytophagous Coleoptera. Journal of Ecology 74, 963-975.

Brown, V.K. \& Southwood, T.R.E. (1987) Secondary succession: patterns and strategies. pp.315-337 in Gray, A.J. \& Edwards, D.J. (Eds) Colonization, succession and stability. Oxford, Blackwell.

Brucker, G. \& Kalusche, D. (1976) Bodenbiologisches Praktikum. Heidelberg, Quelle \& Meyer.

Bürki, H.M. \& Hausammann, A. (1993) Überwinterung von Arthropoden im Boden und an Ackerkräutern künstlich angelegter Ackerkrautstreifen. Agrarökologie 7, 1-158.

Coaker, T.H. \& Williams, D.A. (1963) The importance of some Carabidae and Staphylinidae as predators of the cabbage root fly (Erioischa brassicae). Entomologia Experimentalis et Applicata 6, 156-164.

Cohen, J. (1977) Statistical power analysis for the behavioral sciences. New York, Academic Press.

Collins, K.L., Boatman, N.D., Wilcox, A., Holland, J.M. \& Chaney, K. (2002) Influence of beetle banks on cereal aphid predation in winter wheat. Agriculture Ecosystems and Environment 93, 337-350.

Collins, K.L., Boatman, N.D., Wilcox, A. \& Holland, J.M. (2003) Effects of different grass treatments used to create overwintering habitat for predatory arthropods on arable farmland. Agriculture Ecosystems and Environment 96, 59-67.

Coombes, D.S. \& Sotherton, N.W. (1986) The dispersal and distribution of polyphagous predatory Coleoptera in cereals. Annals of Applied Biology 108, 461-474. 
Dennis, P., Thomas, M.B. \& Sotherton, N.W. (1994) Structural features of field boundaries which influence the overwintering densities of beneficial arthropod predators. Journal of Applied Ecology 31, 361-370.

Desender, K. \& Alderweireldt, M. (1988) Population dynamics of adult and larval carabid beetles in a maize field and its boundary. Journal of Applied Entomology 106, 13-19.

Desender, K.J., Maelfait, J.P., D`Hulster, M.D. \& Vanherche, L. (1981) Ecological and faunal studies on Coleoptera in agricultural land. 1. Seasonal occurrence of Carabidae in the grassy edge of a pasture. Pedobiologia 22, 379-384.

D'Hulster, M. \& Desender, K.J. (1984) Ecological and faunal studies of Coleoptera in agricultural land, IV. Hibernation of Staphylinidae in agro-ecosystems. Pedobiologia 26, 65-73.

Dunger, W. \& Fiedler, H.J. (1997) Methoden der Bodenbiologie. Jena, Fischer.

Frank, T. (1998) Attractiveness of sown weed strips on hoverflies (Syrphidae, Diptera), butterflies (Rhopalocera, Lepidoptera), wild bees (Apoidea, Hymenoptera) and thread-waisted wasps (Sphecidae, Hymenoptera). Mitteilungen der Schweizerischen Entomologischen Gesellschaft 71, 11-20.

Frank, T. \& Nentwig, W. (1995) Ground dwelling spiders (Araneae) in sown weed strips and adjacent fields. Acta Oecologica 16, 179-193.

Freude, H., Harde, K.W. \& Lohse, G.A. (1964) Die Käfer Mitteleuropas, Band 4. Krefeld, Goecke \& Evers.

Freude, H., Harde, K.W. \& Lohse, G.A. (1976) Die Käfer Mitteleuropas, Band 2. Krefeld, Goecke \& Evers.

Good, J.A. \& Giller, P.S. (1986) A contribution to a check-list of Staphylinidae (Coleoptera) of potential importance in the integrated protection of cereal and grass crops. pp. 81-98 in Proceedings of a Meeting of the EC Experts' Group, 25-27 November 1986 Littlehampton, UK, Integrated Crop Protection in Cereals.

Good, J.A. \& Giller, P.S. (1991) The effect of cereal and grass management on staphylinid (Coleoptera) assemblages in south-west Ireland. Journal of Applied Ecology 28, 810-826.

Günter, M. (2000) Anlage und Pflege von mehrjährigen Buntbrachen unter den Rahmenbedingungen des schweizerischen Ackerbaugebietes. Agrarökologie 37, 1-154.

Hengeveld, R. (1980) Food specialization in ground beetles: an ecological or a phylogenetic process? (Coleoptera, Carabidae). Netherlands Journal of Zoology 30, 585-594.

Holopainen, J.K., Bergmann, T., Hautala, E.-L. \& Oksanen, J. (1995) The ground beetle fauna (Coleoptera: Carabidae) in relation to soil properties and foliar fluoride content in spring cereals. Pedobiologia 39, 193-206.

Janetschek, H. (1982) Ökologische Feldmethoden. Stuttgart, Ulmer. Jeanneret, P., Schüpbach, B., Lips, A., Harding, J., Steiger, J., Waldburger, M., Bigler, F. \& Fried, P.M. (1999) Biodiversity patterns in cultivated landscapes: modelling and mapping with GIS and multivariate statistics. pp. 85-94 in Proceedings of the eighth Annual Conference of the International Association for Landscape Ecology, 6-8 September 1999 Bristol, UK, International Association for Landscape Ecology.

Keller, S. (1994) Wozu ökologische Ausgleichsflächen? Landfreund 11, 7-11.

Koch, K. (1989) Die Käfer Mitteleuropas. Ökologie, Band 1. Krefeld, Goecke \& Evers.

Kotze, D.J. \& O'Hara, R.B. (2003) Species decline - but why? Explanations of carabid beetle (Coleoptera, Carabidae) declines in Europe. Oecologia 135, 138-148.

Kromp, B. (1999) Carabid beetles in sustainable agriculture: a review on pest control efficacy, cultivation impacts and enhancement. Agriculture Ecosystems and Environment 74, 187-228.

Kuntze, H., Roeschmann, G. \& Schwerdtfeger, G. (1988) Bodenkunde. Stuttgart, Ulmer.

Lohse, G.A. \& Lucht, W.H. (1989) Die Käfer Mitteleuropas, 1. Supplementband. Krefeld, Goecke \& Evers.

Lys, J.-A. (1994) The positive influence of strip-management on ground beetles in a cereal field: increase, migration, and overwintering. pp. 451-455 in Desender, K.J. et al. (Eds) Carabid beetles - ecology and evolution. Dordrecht, Kluwer.

Lys, J.-A. \& Nentwig, W. (1994) Improvement of the overwintering sites for Carabidae, Staphylinidae and Araneae by strip-management in a cereal field. Pedobiologia 38, 238-242

Lys, J.-A., Zimmermann, M. \& Nentwig, W. (1994) Increase in activity and species number of carabid beetles in cereals as a result of strip-management. Entomologia Experimentalis et Applicata 73, 1-9.

MacFadyen, A. (1961) Improved funnel-type extractors for soil arthropods. Journal of Animal Ecology 30, 171-184.

Mosimann, C. (2002) Diversity of ground beetles (Coleoptera: Carabidae) in relation to habitat age. Diploma thesis, University of Bern.

Nentwig, W. (2000) Die Bedeutung von streifenförmigen Strukturen in der Kulturlandschaft. pp. 1-40 in Nentwig, W. (Ed.) Streifenförmige ökologische Ausgleichsflächen in der Kulturlandschaft. Bern, Verlag Agrarökologie.

Pfiffner, L. \& Luka, H. (2000) Overwintering of arthropods in soils of arable fields and adjacent semi-natural habitats. Agriculture Ecosystems and Environment 78, 215-222.

Purtauf, T., Wolters, V., Tscharntke, T., Schmidt, M. \& Dauber, J. (2002) Landscape complexity and biodiversity of carabids in wheat fields. Verhandlungen der Gesellschaft für Ökologie 32, 34.

Ricketts, T.H., Daily, G.C., Ehrlich, P.R. \& Fay J.P. (2001) Countryside biogeography of moths in a fragmented landscape: biodiversity in native and agricultural habitats. Conservation Biology 15, 378-388.

Schaefer, M. (1976) Experimentelle Untersuchungen zum Jahreszyklus und zur Überwinterung von Spinnen. Zoologisches Jahrbuch Systematik 103, 127-289.

Siemann, E., Haarstad, J. \& Tilman, D. (1999) Dynamics of plant and arthropod diversity during old field succession. Ecography 22, 406-414.

Sotherton, N.W. (1984) The distribution and abundance of predatory arthropods overwintering on farmland. Annals of Applied Biology 105, 423-429.

Sotherton, N.W. (1985) The distribution and abundance of predatory Coleoptera overwintering in field boundaries. Annals of Applied Biology 106, 17-21.

SPSS (2003) SPSS for Windows. Statistics, version 11.5. Chicago, SPSS Incorporation.

Steffan-Dewenter I., Münzenberg, U., Bürger, C., Thies. C. \& Tscharntke, T. (2002) Scale-dependent effects of landscape context on three pollinator guilds. Ecology 83, 1421-1432.

Sunderland, K.D. \& Vickerman, G.P. (1980) Aphid feeding by some polyphagous predators in relation to aphid density in cereal fields. Journal of Applied Ecology 17, 389-396.

Symondson, W.O.C., Sunderland, K.D. \& Greenstone, M.H. (2002) Can generalist predators be effective biocontrol agents? Annual Review of Entomology 47, 561-594.

Ter Braak, C.J.F. \& Smilauer, P. (2002) CANOCO reference manual and CanoDraw for Windows user's guide. Software for canonical 
community ordination (version 4.5). Wageningen and Ceske Budejovice, Biometris.

Thiele, H.U. (1977) Carabid beetles in their environments. Berlin, Springer.

Thomas, M.B., Wratten, S.D. \& Sotherton, N.W. (1991) Creation of 'island' habitats in farmland to manipulate populations of beneficial arthropods: predator densities and emigration. Journal of Applied Ecology 20, 906-917.

Thomas, M.B., Wratten, S.D. \& Sotherton, N.W. (1992) Creation of 'island' habitats in farmland to manipulate populations of beneficial arthropods: predator densities and species composition. Journal of Applied Ecology 29, 524-531.

Thomas, C.F.G., Parkinson, L., Griffiths, C.J.K., Fernandez Garcia, A. \& Marshall, E.J.P. (2001) Aggregation and temporal stability of carabid beetle distributions in field and hedgerow habitats. Journal of Applied Ecology 38, 100-116.
Tomlin, A.D., Miller, J.J., Harris, C.R. \& Tolman, J.H. (1985) Arthropod parasitoids and predators of the onion maggot (Diptera: Anthomyiidae) in southwestern Ontario. Journal of Economic Entomology 78, 975-981.

Topp, W. \& Wiebke, T. (1980) Verteilung und Ausbreitung der epigäischen Arthropoden in der Agrarlandschaft, II. Staphylinoidea. Anzeiger für Schädlingskunde, Pflanzenschutz, Umweltschutz 53, 33-36.

Wiedemeier, P. \& Duelli, P. (1999) Ökologische Ausgleichsflächen und Nützlingsförderung. Agrarforschung 6, 265-268.

Zangger, A., Lys, J.-A. \& Nentwig, W. (1994) Increasing the availability of food and the reproduction of Poecilus cupreus in a cereal field by strip management. Entomologia Experimentalis et Applicata 71, 111-120.

(Accepted 4 February 2004)

(C) CAB International, 2004 
